\title{
Cruising the Colonial: Newspapers and Shop Windows
}

\section{ROGER BLACKLEY}

As the greatest compendium of colonial data, the newspaper is a dangerous drug. My first serious habit followed the disturbing discovery that Alfred Sharpe, a late nineteenth-century artist I was investigating, contributed letters and articles to newspapers not only under his own name, but also using a host of pen-names. Gripped by a weird paranoia, I obsessively scanned semi-legible microfilms that offered up the strange texts I was attributing to Sharpe. After work at the Auckland Art Gallery, I would head to the public library in search of a decent microfilm reader unoccupied by a 'granny-hunter'. This was the mid-1980s, and I was combing through the Auckland papers of the mid-1880s; unsurprisingly, correspondence received at the art gallery would acknowledge receipt of 'your letter dated 8 August $1884 \ldots$...'

On visits to Wellington I consulted the volumes of newspapers then available at the General Assembly Library, delighting in the 'artefactual' quality of the crisp paper - so unlike modern newsprint, yet such a different experience from the murky microfilm. The task wasn't exactly easier, as the large pages were difficult to scan and needed to be turned with care, but I revelled in the definitive magic of the 'real thing'. In drug terms, this was pure heroin in comparison with the degraded, sometimes barely legible microfilm. The physical newspaper allowed an entirely different understanding of its nature, including how the densely inked type made impressions into a paper stock that possessed real heft. Now, three decades on, we have Papers Past and other digital databases that can slice right through to the desirable nuggets in their hundreds and thousands. Papers Past is surely the crack cocaine of newspaper research: a 'substance' that enables the collection in a single hour of what previously could have required an entire month - if you were lucky. ${ }^{1}$

Everyone agrees that word-searchable newspaper databases have revolutionized the acquisition of historical data, now no longer the exclusive prize of painstaking excavation in libraries but instead available to anyone with a computer screen. Papers Past seemingly furnishes evidence of anything and everything, though its deployment still demands a combination of knowledge, stamina, intuition and luck, and the same question remains: what do we want to know? Nevertheless, word-searchability has profoundly 
altered the nature of what we might term 'unfocused' research, akin to browsing a library shelf, open to serendipitous discoveries that might modify the interpretive scope of a project.

My quest for Sharpe and his world-view had widened into an investigation of the display culture in which he participated. While there were secondary histories that covered aspects of the elite art-society showings and international exhibitions of the period, the newspapers opened another colonial art to view: an everyday visual culture that was quite literally addressed to the street. In the received art history, the 1870s in New Zealand saw the first, faltering beginnings of art societies and museums. This is indeed the case, at least for centres such as Dunedin and Auckland, but even there such intermittent and socially exclusive initiatives were merely supplementing a wider and more vibrant culture of shop-window exhibitions. It was a phenomenon not only of the cities but of smaller towns as well, in a period when the street was the definitive public space. As I began to discover, the shop windows were hosting a colonial art culture far more diverse than the art-historical stereotype of colonial art had allowed.

The shop window offered an ideal habitat for a quirky sub-genre of illusionistic drawings, whereby the barrier of the window pane served to enhance the eye-deceiving potency of the artefact. When in 1998 the Auckland Art Gallery acquired an unusual 1877 ink and watercolour drawing by William F. Gordon, I blithely assigned the title Trompe l'œeil (Plate 1). Now I know that this could never have been its title, for a search of Papers Past immediately provides the negative evidence: not a single appearance of 'trompe l'œil'. But if you enter the expression 'optical illusion' one of your rewards will be an article in the Wanganui Chronicle of 3 February 1877, titled 'Work of Art'. ${ }^{2}$ It describes the first exhibition of this very drawing, in 'Mr Bowden's shop window, in Victoria Avenue'. E.S. Bowden was then intent on transforming a book and stationery store into a Fancy Goods Repository dealing in music and musical instruments, opera glasses, albums, toys, dolls and vases. ${ }^{3}$

The 30-year-old William Gordon worked in the Wanganui telegraph office - at the time a cutting-edge occupation, like IT today. He involved himself in a myriad of leisure activities, including music and stage performance, but the illusionistic drawings are his most compelling legacy. The Chronicle's writer recalled earlier examples of Gordon's penmanship that were outdone by this new 'chef d'euvre': 'When first one glances over the collection of articles which are there represented, he finds it difficult to believe that their substantial existence is merely an optical illusion.' The writer noted that the Bank of New South Wales pound note, 'even after careful observation,

Opposite: Plate 1. William F. Gordon, Trompe l'œil January 1877, pencil, ink and watercolour, 530 x 710 mm (Auckland Art Gallery Toi o Tamaki; The llene and Laurence Dakin Bequest, 1998). 
Newspapers and Shop Windows

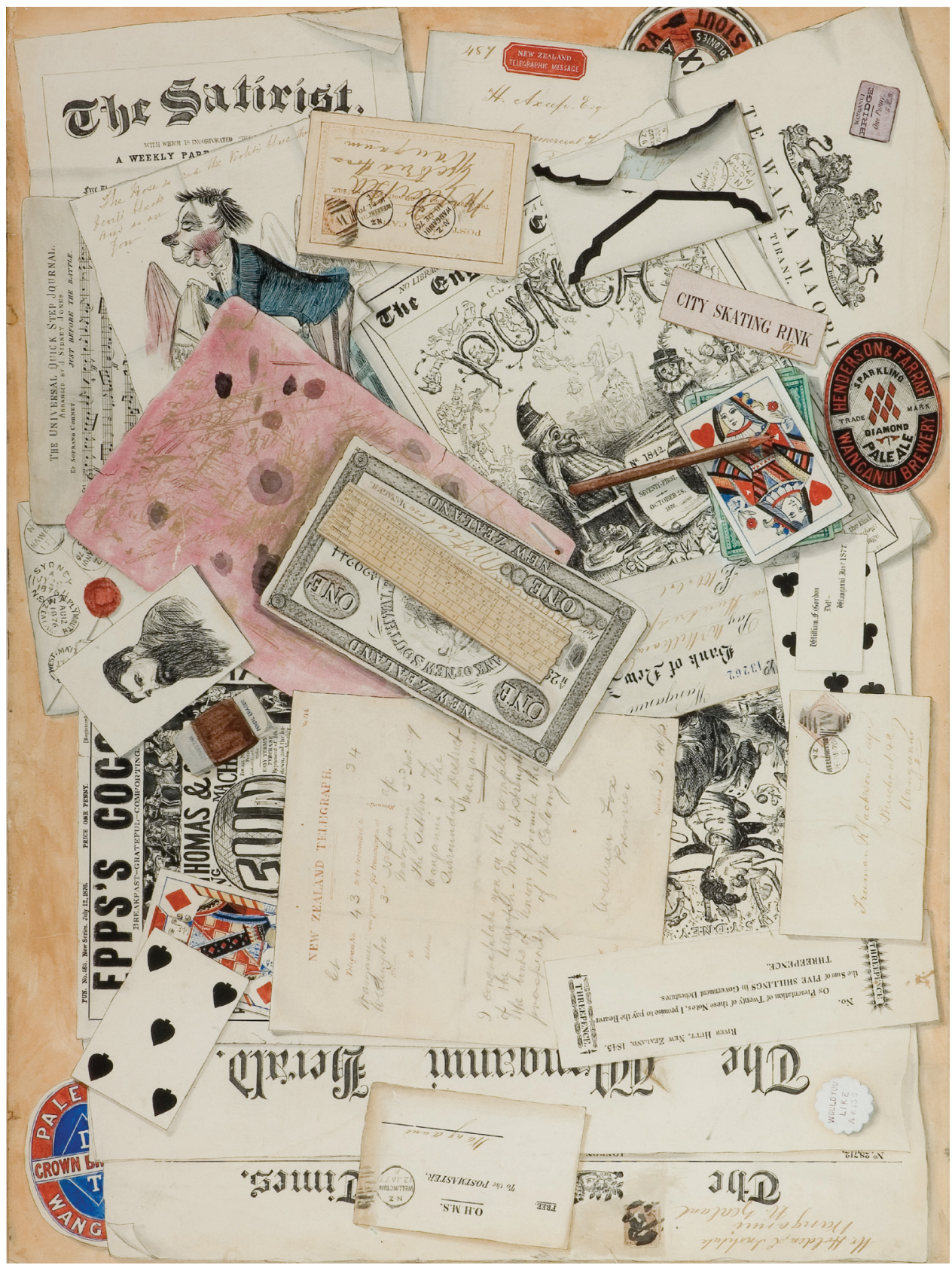


Journal of New Zealand Studies

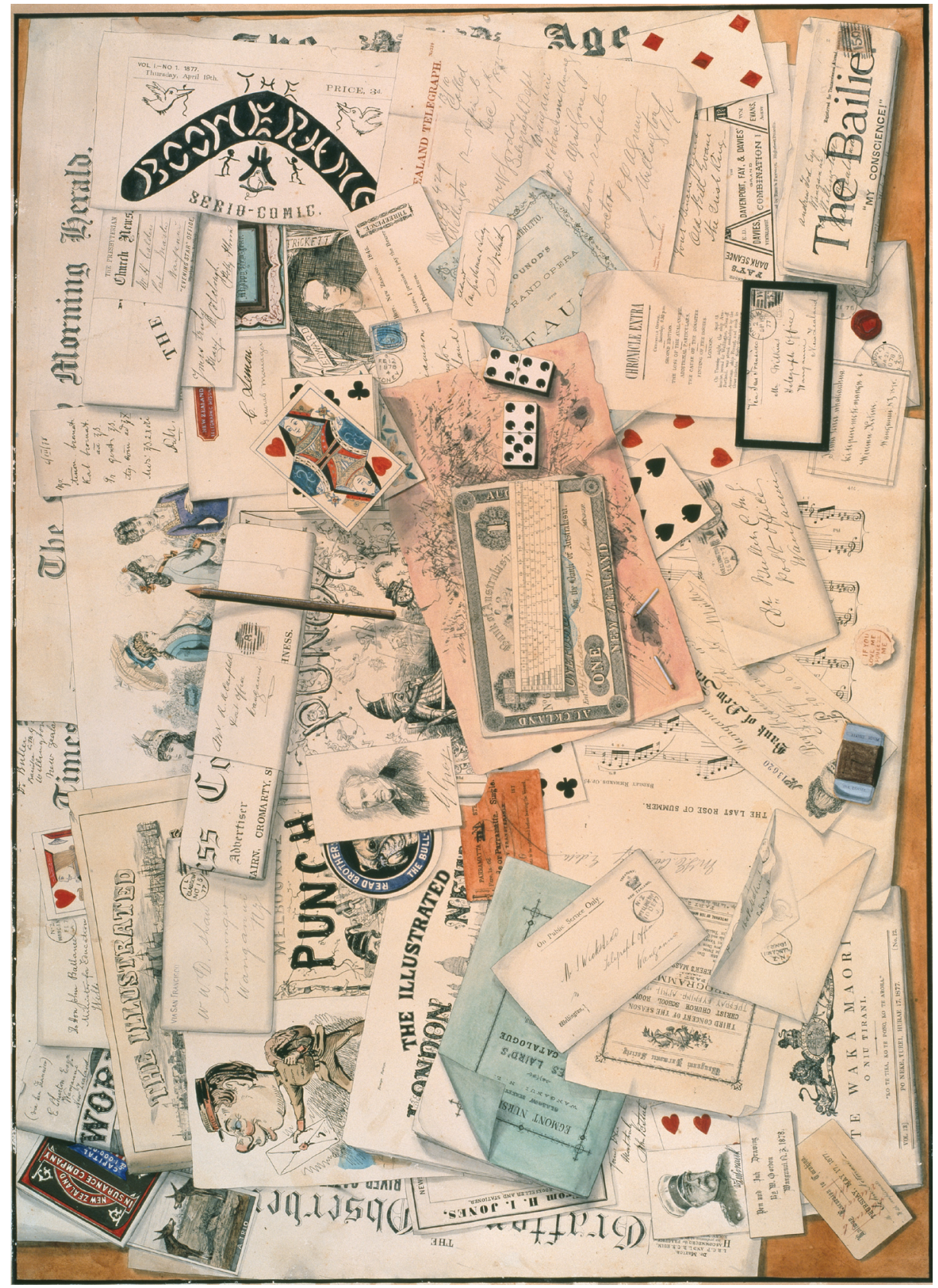


appears a genuine article, specially attractive, in being apparently easily transferable to the purse', causing the 'mystified beholder to rub his eyes, in the effort to undeceive himself of the optical deception, thus involuntarily though potently, persuading him against his actual belief and practical judgment'. Far from the conventional language of a fine art review, the text instead links itself to a wider world of entertainment that is referenced in the work itself: beer labels, playing cards, satirical journals such as Fun and the Sydney Punch, a ticket for the City Skating Rink. Partly obscured by the stained blotting paper is the wood-engraved representation of some kind of illusionist, possibly a work by Gordon, who claimed to have introduced the use of the New Zealand hardwood akeake to Australian wood-engravers. ${ }^{4}$

To the immediate left of the pound note is a transcribed telegram, an important relic belonging to Wanganui's telegraph office. It is the 1869 message from the premier, William Fox, congratulating the community on its connection to the telegraph. This was the event that finally shattered Wanganui's isolation on the northern shore of the Whanganui River, further lessened in 1871 by the completion of a bridge across the enormous river. At the bottom right, Gordon has strategically placed a one-penny bridge ticket on a copy of Te Waka Maori, referencing the role played by the bridge in changing the nature of communication between Pākehā Wanganui and the Māori community on the other side of the river. The most distant channel of communication lurks at the lowest stratum of the composition, visible in one corner - a copy of the London Times addressed to Mr Holden of 'The Institute, Wanganui'. This was the Mechanics' Institute library that had recently been incorporated into a public library. In May 1878, in reply to a complaint about the scarcity of journals at the reading room, the Wanganui Herald informed its readers that 'there are 18 colonial journals always to be found on the table, the dates being the very latest to hand'. ${ }^{5}$ In a town consisting of barely 5000 inhabitants, such a collection represented a vital resource for both education and entertainment.

Ten years ago I organized an exhibition of illusionistic tabletop drawings at Victoria University of Wellington's Adam Art Gallery, mounting a seemingly implausible argument that these playful works deserved recognition as colonial history painting. ${ }^{6}$ Rather than peripheral isolation, these essentially autobiographical statements seemed to be asserting colonial modernity and connectedness by insistently referencing newspapers (the colonial literature par excellence) as well as letters, postcards and the new instantaneous communication of the telegraph. ${ }^{7}$ Gordon's adoption of this illusionistic still-life genre, I further argued, was almost certainly generated by an encounter with a similar work exhibited in a Wellington shop window five

Opposite: Plate 2. William F. Gordon, Stray Leaves 1878, pencil, ink and watercolour, 652x 910 mm (Whanganui Regional Museum Collection; bequest of William F. Gordon, 1936). 
years earlier. This catalysing agent was Harry C.W. Wrigg's Leisure Hours, now known only through a photograph but which in August 1872 provided a fascinating exhibit in the show window of William Lyons' stationery and bookshop on Lambton Quay. ${ }^{8}$

A year and a half earlier, in December 1870, Harry Wrigg created a stir in Auckland when the window of Charles Upton's Queen Street bookshop unveiled another of his elaborate illusionistic drawings. A government draftsman working on the Thames goldfield, Wrigg cannily tailored his drawing to include a reference to the visiting Duke of Edinburgh, Victoria's son Prince Alfred and New Zealand's first royal visitor. The drawing was subsequently donated by Wrigg to the All Saint's bazaar, a fund-raiser under the patronage of the governor's wife, and it was Lady Bowen who persuaded the prince to add a royal signature to the work and thereby enhance its value for the raffle. According to the New Zealand Herald, '[v]arious and very curious were the remarks made by those standing looking at it', estimates of its value ranging from $£ 20$ to $£ 100 .{ }^{9}$ These are enormous sums in relation to contemporary art valuations: in 1876 Alfred Sharpe priced his early masterpiece Taupiri Village and Plain at eight guineas. What we must regret in this case is the fatal combination of royal avarice and patriotic sentiment that led to Wrigg's drawing being presented to the prince, since it resulted in the loss of a work which might have logged Harry Wrigg as a significant artist of the period..$^{10}$ Instead, his fate has been virtual oblivion.

Besides Charles Upton, another Queen Street bookseller of the 1870s who collaborated with artists was Edward Wayte, who advertised his shop as 'Auckland's Library'. ${ }^{11}$ Wayte's window showed an unfolding cornucopia of local art and craft, including local decorative products such as pottery by James Wright and fine inlaid work by the cabinetmaker Walter Bayne. ${ }^{12}$ These alternated with the work of watercolourists such as J.C. Hoyte and Alfred Sharpe. Sharpe's iconic Pohutukawa was described by a journalist looking through a window as 'worked up with almost Pre-Raffaelite precision'. ${ }^{13}$ While the price is not indicated, in the opinion of the commentator 'the artist will be but poorly repaid for his time and trouble by receipt of the small sum demanded for this exquisite picture'.

The art union was an institution roughly equivalent to the solo shows staged by artists today. I remember my mother regularly buying 'art union' tickets, which by the mid-twentieth century had come to refer simply to a lottery with a cash prize. In the nineteenth century the art union signified a raffle in which the purchase of a ticket gave you a strong chance of winning a significant work of art. The events required the express permission of the colonial secretary and were drawn under police supervision, thereby bequeathing invaluable archival traces which can include the precise finances of the event. The names of the winners were published in the newspapers, 
so in addition to the art valuations we can learn the identity of the earliest collectors of named works. It can be uncanny when, almost a century and a half later, a work is traced to the possession of a descendant with that same surname.

The economic evidence provided by the art unions can be more poignant than triumphant, as when down-at-heel artists are listed as winning their own works. In order for the draw to proceed, underappreciated artists were obliged to buy up tickets themselves. An example is Thomas Drummond's 1877 art union at Upton's, in which the artist himself won the 3rd, 7th, 13th, 16th, 17th and 20th prizes. ${ }^{14}$ The Herald reported that, despite the nominal 120 members of the art union, in reality there were only 70, 'the remaining 50 chances being retained by Mr Drummond'. The typical value of an art union in the 1870s was 100 tickets at 10 shillings each, with the value of the prizes adding up to the $£ 50$ of revenue.

Upton's showed an extremely wide range of work by other artists, including many of the presentation pieces commissioned from Auckland's marquetry expert, Anton Seuffert. In early 1870, for example, Upton's window showed the elaborate escritoire, or desktop writing compendium, presented to Archdeacon Lloyd by the clergy of Auckland..$^{15}$ Seuffert also produced speculative pieces such as inlaid boxes and album covers, and the spectacular drawing-room tables that routinely raised amounts exceeding anything achieved by even the most impressive of contemporary paintings. In 1875, for example, the first prize in Seuffert's art union was a table valued at $£ 100 .{ }^{16}$ Like the illusionistic drawings of Wrigg, Seuffert's highly valued masterpieces of inlaid native woods belonged to the dynamic side of the colonial art economy.

Occupying a similar niche dedicated to the supply of elite gifts, jewellers' shop windows showed pieces in colonial gold that likewise asserted their status as local productions. In June 1870 Richard Beck displayed an 'emblematical brooch' including 'a view of Mount Egmont, with a foreground of a kiwi, a tree fern, a flax bush, and a canoe manned by natives' that was 'admirably suited for a "home" gift'. ${ }^{17}$ The inevitable accompaniments of such gifts were photographic portraits, which simultaneously contributed to the enticing displays maintained by photographic studios. These were the portrait galleries of the period that were available for browsing by anyone on the street, leading to their co-option for lonely hearts purposes. ${ }^{18}$ Nevertheless, the mass-reproducible and cheaply marketed photograph needs to be distinguished from the unique, handcrafted artefact that carries a steep price or is even declared to be priceless, precisely because it is serving a higher purpose.

It was in another Wanganui shop window that Gordon unleashed a second, far more ambitious exercise in illusionism. The 1876 picture had provided 
the basis for a successful art union staged by Bowden in early 1877 which, with 100 tickets at 5 shillings a throw, generated an impressive gross of $£ 25 .{ }^{19}$ Inspired by this critical and financial success, Gordon devoted four months of the following summer to realizing the spectacular piece that he unveiled in late March 1878 in the window of H.I. Jones's stationery store on Victoria Avenue (Plate 2). This is the work he eventually titled Stray Leaves and bequeathed to Whanganui Regional Museum. I called my exhibition after it. All this was back before Papers Past and I had mistakenly selected the Wanganui Chronicle in a vain attempt to trace some kind of early reception history for the work, since I was able to access the hard copies in the basement of the museum. Despite this access, however, I failed to notice that paper's appreciative notice of the exhibition in Jones's window. ${ }^{20}$

Papers Past now tells me that I would have been better off looking in the Wanganui Herald, which documents an early 1878 exhibition trajectory of a triumphant Saturday evening showing in Jones's window, followed by display in Wanganui's City Hall with a shilling entry fee, and then to the Sydney Exhibition. ${ }^{21}$ This was not the massive Sydney International Exhibition of 1879, but rather the Easter 1878 show of the Agricultural Society of New South Wales, where the entire category of works of art suffered a reversal of prestige by occupying a subservient position under the heading 'Non Agricultural Produce'. Under the title The Study Table, Gordon's masterpiece won a bronze medal ('four inches in diameter') bearing the inscription 'Practice with science, W. Gordon, pen and ink drawing, $1878{ }^{\prime 22}$ In November of that year, the Herald recorded that Jones's window now featured the medal that confirmed Gordon's success: 'We believe that this is the first award of any consequence gained for art by any resident in Wanganui, and it therefore will be the subject of much interest to the public and congratulation to the fortunate winner. ${ }^{23}$

There is no question that Gordon's contemporaries regarded his drawings as colonial fine art - worthy of investment on the part of subscribers to an art union, their elevated status confirmed by trans-Tasman recognition. Interestingly, Gordon's work was more highly valued in Wanganui than was Sharpe's in Auckland; though both paled in comparison with the status accorded the work of a celebrated cabinetmaker such as Seuffert. The histories generated by the shop window displays of this period - effectively, the earliest reception of an extraordinary range of art - are important because the lacunae in institutional and collection histories can blur our understanding of the earliest contexts of many works. Stray Leaves (under the title Study Table) later travelled to Sydney and Melbourne for their respective international exhibitions of 1879 and 1880, winning a bronze at the former; it won a silver medal at the 1882 Christchurch Exhibition and, following Gordon's move to New Plymouth, appeared there in exhibitions. ${ }^{24}$ 
Even his earlier trompe l'œil drawing reappeared for the enormous 1887 show with which Wanganui marked Queen Victoria's Jubilee. ${ }^{25}$ While remaining aloof from art society exhibitions, Gordon's work nevertheless played an extremely active role in the demotic display culture of his time.

I have written at length on the iconography of Stray Leaves and will here only point to a couple of salient elements. Firstly, the calligraphic label in te reo Māori - I taia tenei whakaahua ki te pene me te mangu e Wiremu Kotene [drawing done in pen and ink by William Gordon] - was made by Gordon's friend Walter Williams Hipango, a law clerk whose father died while attempting to mediate an 1865 battle at Ohautahi. Is this a rare case of bilingual titling? Or simply an exercise in colonial exoticism? ${ }^{26}$ It is undeniably Pākeha Wanganui that is addressed in Gordon's work, at times in a very visceral sense. For example, the black-bordered mourning letter at lower right: addressed to 'Mr Wilkins, Telegraph Office, Wanganui', the envelope is juxtaposed with the Wanganui Chronicle's announcement of the sinking of the Avalanche off Portland, Oregon in September 1877. Gordon later wrote to his friend Horace Fildes of the uncanny circumstances of Wilkins transcribing an international telegram when he realized it concerned the loss of the ship carrying his entire family back to New Zealand. ${ }^{27}$ Without knowing the particularities of this story we can nevertheless see that these two elements, so carefully juxtaposed, must be related. A narrative that was so immediately accessible to the work's first audience in Wanganui - 25 of whose citizens perished on the Avalanche - in time disperses its topicality to serve as a more generalized reference to mortality.

Gordon's phantasmagoric drawings were designed to tantalize their viewers by simultaneously concealing and revealing information, and their interpretation depends as much on the interactive reader as on the originating author. It's a bit like the historical archive itself, where the facts to be excavated depend more on the researcher than the archive. Papers Past and the flâneur-like browsing it encourages - an endless, addictive quest through thickets of 'Untitled' and 'Page 2 Advertisements' in search of that elusive, epiphanic text - brings to mind queer theorist Simon Ofield's notion of research as cruising. As Ofield explains, '[h]istorians, theorists and psychoanalysts collect evidence, interpret clues, make inferences and work toward a clear and explicit view of what is only suspected. ${ }^{28}$ Cruising is the polar opposite of targeted research which sets out simply to find evidence to support a pre-existing conclusion, and it is an approach that can have productive results. My first meeting with Gordon and Wrigg, in the form of photographic traces of their work, occurred while surfing the New Zealand ephemera at Sydney's Mitchell Library, and my first encounter with the artefactual Stray Leaves occurred unexpectedly during a visit to the Whanganui Regional Museum. On display in a small frame alongside 
Stray Leaves was a collection of the medals it had won, which Gordon had also bequeathed to the museum.

I am aware that this essay exemplifies an 'art historical' approach, one that accords a privileged status to its objects of research - the paintings, collections, displays. I can hear the sceptical voice of the historian of material culture asking whether these eye-deceiving drawings by Gordon or Wrigg were not simply one category among the multiplicity of commodities on offer in the shop windows of the 1870s. Why should the art-historical cult of the authentic object bestow an autonomy allowing these works to possess something akin to a 'career'? The art-historical counterargument would stress the historical consciousness that distinguishes these playful works and their apparent determination to address posterity. While focused more on the singular than the generic, art history has nevertheless always concerned itself with the social life of 'things' and their makers. It is a compelling irony that the historical sense of the past evoked by Gordon's drawings - the fantasy of an 'archive' accessible through material culture preserved in archives and museums - is now delivered in an amazingly deep fashion, courtesy of Papers Past. It's a little like the ultimate paradox offered by the successful evocation of an authentic mess, where artfully layered artefacts set up a complicated visual game. For it is precisely in the creation of these ambitious drawings that Gordon reveals how his scintillating fantasy of disorder lay at the command of an artist possessed of consummate organizational skill and genuine graphic panache.

1 The digital 'miracle' is almost entirely (and very cheaply) built on the earlier technology of microfilm, the deficiencies of which seriously impact on the optical character recognition software. In her recent critique of Papers Past as a 'dodgy source', Caroline Daley seems unaware that some of the flaws are related to these celluloid origins: 'Papers From the Past, and Problems From the Present', Turnbull Library Record, 43 (2010-11), pp.64-72.

2 'Work of Art', Wanganui Chronicle (WC), 2 February 1877, p.2.

3 Bowden's business soon failed, with increasingly desperate sales lasting throughout 1877.

4 The elaborate inlaid chessboard exhibited by Anton Seuffert at the 1879 Sydney International Exhibition incorporated 'the celebrated ake-ake, which has been found useful for the wood engraver's art for book and newspaper illustrations, and which was introduced into Sydney some few years ago by the then proprietor of "Sydney Punch" through Mr W. Gordon of Wanganui': 'The Sydney Exhibition', Hawke's Bay Herald, 27 October 1879, p.3.

5 Wanganui Herald (WH), 11 May 1878, p.2.

6 Roger Blackley, Stray Leaves: Colonial Trompe l'œil Drawings, Wellington, 2001. See also Roger Blackley, 'Colonial Illusions: Australasian Trompe l'œil Drawings', in 
Timothy Barringer, Geoff Quilley and Douglas Fordham, eds, Art and the British Empire, Manchester, 2007, pp.67-83.

7 The primacy of print media in colonial culture, and the newspaper in particular, was influentially argued by Benedict Anderson in Imagined Communities: Reflections on the Origin and Spread of Nationalism, London, 1993. For confirmation of the close links between print culture and the trompe l'œil still lifes, see David Finkelstein, “'Jack's as Good as His Master": Scots and Print Culture in New Zealand, 1869-1900', Book History, 6, (2003), pp.95-107.

8 Evening Post (EP), 2 August 1872, p.2.

9 'Bazaar: Mr Wrigg's Drawing', New Zealand Herald (NZH), 29 December 1870, p.2.

10 'The Duke of Edinburgh, however, took a great fancy to the drawing, and Mr Brown [winner of the work in the art union raffle] was persuaded to give it to him, His Serene Highness promising that on his return to England he would bear Mr Brown's kindness in mind and make him an adequate return for the picture. But, as may be imagined by those who remember the royal Alfred, that was the last Mr Brown ever heard of the matter. His Highness of Edinburgh was nothing if not stingy': 'The Fretful Porcupine', Observer, 22 September 1894, p.7. Enquiries to the Royal Collection and Coburg Castle in search of Wrigg's drawing have proved fruitless.

11 Bookshops serving as circulating libraries are discussed by Judith Elphick, 'Culture in a Colonial Setting: Auckland in the Early 1870s', New Zealand Journal of Educational Studies, 10, 1 (May 1975), p.4. Though distilled from the newspapers of the period, Elphick's panoramic survey of culture in Auckland completely overlooks the thriving culture of shop-window exhibitions.

12 NZH, 29 May 1878, p.2.

13 NZH, 3 February 1876, p.2.

14 NZH, 27 January 1877, p.2.

15 Evening Star (ES), 25 April 1870, p.2; Daily Southern Cross (DSC), 3 May 1870, p.7.

16 'Grand Art Union at the Choral Hall', DSC, 24 November 1875, p.1.

17 ES, 6 June 1870, p.3.

18 For an 1876 romance that was sparked by an alluring carte-de-visite displayed by an Auckland photographer, see ES, 29 December 1876, p.2.

19 For the results of Bowden's art union, see WH, 10 February 1877, p.2. First prize was Gordon's illusionistic drawing; 'second prize is an illuminated piece of poetry from the hands of the same gentleman': WH, 29 January 1877, p.2. On this latter work, see 'Ornamental Penmanship', WC, 7 February 1877, p.2. Other prizes included oleographs, a graphoscope, musical album and photographs of Gordon's drawing.

20 'A Work of Art', WC, 27 March 1878, p.2.

21 'Mr Gordon's pen and ink sketch. This wonderful triumph of industry and skill will be exhibited at my office, City Hall, previous to shipment for the Sydney Exhibition ... Alfred McMinn, Agent': WC, 27 March 1878, p.3.

22 EP, 30 October 1878, p.2.

23 WH, 5 November 1878, p.2.

24 For Gordon's bronze medal from the Sydney International Exhibition, see WH, 18 August 1880, p.2; for the silver from Christchurch, WH, 29 May 1882, p.2. For showings in New Plymouth: 'Jubilee Exhibition', TH, 7 April 1891, p.2; 'The Carnival and Exhibition', TH, 28 December 1904, p.2. 


\section{Journal of New Zealand Studies}

25 'The Jubilee Exhibition', WH, 17 June 1887, p.2.

26 The original calligraphy was included in Gordon's bequest to the museum.

27 'A Tragedy of 1877: Loss of the Avalanche', TH, 26 May 1934, p.3.

28 Simon Ofield, 'Cruising the Archive', Journal of Visual Culture, 4, 3 (2005), p.362. 